胃癌切除後胆石症について

一発生頻度を中心に一

\begin{tabular}{|c|c|c|c|c|c|c|}
\hline \multicolumn{7}{|c|}{ 弘前大学第 2 外科 } \\
\hline 杉山 & 小澤 & 正則 & 三上 & 泰德 & 羽田 & 隆吉 \\
\hline 志田 正一 & 戸張 & 雅晴 & 森谷 & 洋 & 遠藤 & 正章 \\
\hline $\begin{array}{l}\text { 宮城島 堅 } \\
\text { 小野 慶一 }\end{array}$ & 吉田 & 尚弘 & 福島 & 紀雅 & 今 & 充 \\
\hline
\end{tabular}

\title{
INCIDENCE OF GALLSTONE DEVELOPMENT AFTER RADICAL GASTRECTOMY FOR GASTRIC CANCER
}

\author{
Yuzuru SUGIYAMA, Masanori OZAWA, Yasunori MIKAMI, \\ Ryukichi HADA, Shoichi SHIDA, Masaharu TOBARI, \\ Hiroshi MORIYA, Masaaki ENDOH, Ken MIYAGISHIMA, \\ Naohiro YOSHIDA, Norimasa FUKUSHIMA, Mitsuru KONN \\ and Keiichi ONO \\ Department of Surgery, Hirosaki University, School of Medicine
}

昭和50年 58年までの胃癌切除患者を対象に胆道の超音波検查を施行，胃癌切除後胆石症について 検索した。最終検查施行時までの術後経過期間は $1 \sim 10$ 年, 対象は便宜上A (147例)， B (85例), C （99例）の 3 群に大別，比較した。術後経過期間の長い A, B 群をあわせてみると胆石発見率は $21.8 \%$ であった．男女別発見率は男 $21.9 \%$ ，女 $21.4 \%$ と性別差はなかった。胃切除術式別発見率は亜全摘 $21.5 \%$, 全摘 $22.2 \%$ と切除術式による差異はなかった。胃再建術式別発見率については A, B 群の術式 にかたよりがあるため, C群症例の積み重ねが必要である. 胆石発見時期は A, B 群の $81.3 \%$ 症例が 5 年以内に発見されていることより, 本症の経過観察には胃癌切除後最低 5 年必要と思われた.

索引用語：胃切除後胆石症, 胃癌切除後胆石症

I.はじめに

胃切除後に発生する胆石症の頻度は, その原因の一 つと考兄られている迷走神経切離（以後迷切之略）の 有無および程度による大きく異なると考えられてい る. その点著者らの胃癌切除後胆石症 ${ }^{12)}$ (以後胃切胆 石症と略) ではいずれの症例も第 2 群リンパ節郭清を 行う，いわゆる $\mathrm{R}_{2}$ 手術(以後 $\mathrm{R}_{2}$ 手術と略)以上である ため, 全例完全な全幹迷切(以後幹迷切と略)例といっ てよい. したがって本症の発生頻度, 特に切除術式別 括よび再建術式別の頻度を比較検討するには迷切の程

$<1985$ 年11月12日受理 >別刷請求先：杉山 讓

厂036 弘前市在府町 5 弘前大学医学部第 2 外科
度が同じため，すこぶる都合がよい対象群といえる。

そこで昭和 58 年に本誌に発表したデータ1をもとに さらに症例を重ね, 観察期間の延長により胃切後胆石 症の発生頻度についてある程度の知見が得られたので 興味ある経過をとった症例とともに報告する。

\section{II. 対象わょひ結果}

対象を便宜上以下の 3 群に分け検討した。 まず，A 群として昭和 50 年 1 月より 55 年 12 月までの $\mathrm{R}_{2}$ 手術患 者中昭和56年 9 月 1 日現在生存していたるので当時の 胆道の超音波検査（以後 USG と略）に応じた147例と した(な拉，資料不備のため前迷のデータ1)より 1 例削 除した).

B群としてA群の患者中胆石の存在を指摘された 19 
例を除き, 昭和 56 年の USG 以降60年 3 月まで 6 カ月 ごとの定期的 USG に応じた85例を選んだ．したがっ てB群は術後 $4 \sim 10$ 年経過例である.

$\mathrm{C}$ 群は昭和 $56 \sim 58$ 年までの $\mathrm{R}_{2}$ 手術患者中 $\mathrm{B}$ 群と同様 に 6 カ月ごとの定期的 USG を受けた99例で, 術後 1 ～4年経過例である.なお, 手術時平均年齢はA群56 歳, B 群55歳，C群57歳とほぼ同様であった。 また, 男女別頻度子A群1.6：1, B群 $1.4 ： 1$, C 群 $1.5 ： 1$ と差はなかった。

胆石発見率は表 1 のごとく A 群147例中19例,

表 1 胆石発見頻度

\begin{tabular}{c|c|c|c}
\hline & 検索症例 & 胆石発見症例 & 胆石発見率(\%) \\
\hline A 群 & 147 & $19[32]$ & $12.9[21.8]$ \\
B 群 & 85 & 13 & 15.3 \\
C 群 & 99 & 10 & 10.1 \\
\hline
\end{tabular}

了内：B群の胆石発見症例を $\mathrm{A}$ 群に加光たもの

表 2 男女別胆石発見頻度

\begin{tabular}{c|c|c|c|c}
\hline & 性別 & 検索症例 & 胆石発見症例 & 胆石発見率(\%) \\
\hline \multirow{2}{*}{ A 群 } & 男 & 91 & $11[20]$ & $12.1^{* 1}[21.9]$ \\
& 女 & 56 & $8[12]$ & $14.3[21.4]$ \\
\hline \multirow{2}{*}{ B 群 } & 男 & 50 & 9 & $18.0^{* 2}$ \\
& 女 & 35 & 4 & 11.4 \\
\hline \multirow{2}{*}{ C 群 } & 男 & 60 & 7 & $11.7^{* 3}$ \\
& 女 & 39 & 3 & 7.7 \\
\hline
\end{tabular}

〔〕内：B群の胆石発見症例を $\mathrm{A}$ 群に加えたすの

百分率の検定 $* 1 \sim * 3$ いずれも $\mathrm{P}>0.05$
$12.9 \%, \mathrm{~B}$ 群 85 例中 13 例, $15.3 \%$ であった. 今, 仮り にB 群の胆石発見症例13例を $\mathrm{A}$ 群に組み入えると胆石 発見率は147例中 32 例, $21.8 \%$ に上昇する.C群は99例 中10例，10.1\%であった，胆石発見例における術前 USG 施行率はA 群19例中 5 例, $26.3 \% ， \mathrm{~B}$ 群 13 例中 11 例, $84.6 \%$ ， C群10例中10例，100\%であった. 術前, 術後の USG がルーチン化されたのは昭和54年以降で ある。

男女別胆石発見率はA 群では男91例中11例, 12.1\%, 女56例中 8 例， $14.3 \%$ と羑はなく，B群は男 50 例中 9 例， $18.0 \%$ ，女 35 例中 4 例， $11.4 \%$ 之男に多い傾向に あったが有意差はなかった。ここでB群の胆石発見症 例を A群に加光ると男91例中 20 例， $21.9 \%$ ，女56例中 12例, 21.4\%に増加するが矢張り性別差はみられない。 C 群は男60例中 7 例, $11.7 \%$, 女39例中 3 例, $7.7 \%$ と 男に多い傾向にあった（表 2 ）.

胃切除術式別胆石発見率はA群では胃亜全摘93例中

表 3 胃切除術式別胆石発見頻度

\begin{tabular}{c|c|c|c|c}
\hline & 術式 & 検索症例 & 胆石発見症例 & 胆石発見率(\%) \\
\hline \multirow{2}{*}{ A 群 } & 胃亜全摘 & 93 & $12[20]$ & $12.9^{* 1}[21.5]$ \\
& 胃 全 摘 & 54 & $7[12]$ & $13.0[22.2]$ \\
\hline \multirow{2}{*}{ B群 } & 胃亚全摘 & 56 & 8 & $14.3^{* 2}$ \\
& 胃 全 摘 & 29 & 5 & 17.2 \\
\hline \multirow{2}{*}{ C 群 } & 胃亜全摘 & 65 & 5 & $7.7^{* 3}$ \\
& 胃 全 摘 & 34 & 5 & 14.7 \\
\hline
\end{tabular}

〔〕内：B群の胆石発見症例をA群に加えたもの 百分率の検定 $* 1, * 2 \mathrm{P}>0.05, * 3 \mathrm{P}<0.05$

表 4 胃再建術式別胆石発見頻度

\begin{tabular}{|c|c|c|c|c|}
\hline & 術 式 & 検索症例 & 胆石発見症例 & 胆石発見率(\%) \\
\hline $\mathrm{A}$ 群 & $\begin{array}{l}\bigcirc\left\{\begin{array}{l}\text { B-I } \\
\text { 空腸間置 }\end{array}\right. \\
\Delta\left\{\begin{array}{l}\text { B-II } \\
\rho \text { 吻合 }\end{array}\right.\end{array}$ & $\left.\begin{array}{c}1 \\
92 \\
54\end{array}\right\} 146$ & $\left.\left.\begin{array}{c}0 \\
12 \\
7\end{array}\right\} 19\left[\begin{array}{l}19 \\
12\end{array}\right\} 31\right]$ & $\left.\left.\begin{array}{c}0 \\
13.0 \\
13.0\end{array}\right\} 13.0\left[\begin{array}{l}20.7 \\
22.2\end{array}\right\} 21.2\right]$ \\
\hline B群 & $\begin{array}{l}O\left\{\begin{array}{l}\mathrm{B}-\mathrm{I} \\
\text { 空腸間置 }\end{array}\right. \\
\Delta\left\{\begin{array}{l}\mathrm{B}-\mathrm{II} \\
\rho \text { 吻合 }\end{array}\right.\end{array}$ & $\left.\begin{array}{l}2 \\
54 \\
29\end{array}\right\} 83$ & $\left.\begin{array}{l}1 \\
7 \\
5\end{array}\right\} 12$ & $\left.\begin{array}{l}50.0 \\
13.0 \\
17.2\end{array}\right\} 14.5$ \\
\hline C群 & $\begin{array}{l}O\left\{\begin{array}{l}\mathrm{B}-\mathrm{I} \\
\text { 空腸間置 }\end{array}\right. \\
\Delta\left\{\begin{array}{l}\mathrm{B}-\mathrm{II} \\
\text { o吻合 }\end{array}\right.\end{array}$ & $\left.\begin{array}{l}45 \\
10\end{array}\right\} 55$ & $\left.\begin{array}{l}3 \\
2\end{array}\right\} 5$ & $\left.\begin{array}{r}\begin{array}{r}6.7 \\
20.0\end{array} \\
10.0 \\
12.5\end{array}\right\} 11.4$ \\
\hline
\end{tabular}

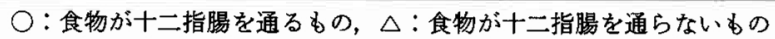

〔 ]内：B群の胆石発見症例をA群に加えたすの

百分率の検定 $* 1 \quad \mathrm{P}>0.05$ 
12例， $12.9 \%$ ，胃全摘 54 例中 7 例, $13.0 \%$ と差はなく, B 群でも胃㩊全摘 56 例中 8 例， $14.3 \%$, 胃全摘 29 例中 5 例, $17.2 \%$ と胃全摘に多いるのの有意差はなかった。 $\mathrm{B}$ 群の胆石発見症例を $\mathrm{A}$ 群に組み入れると胃覀全摘 93 例中 20 例， $21.5 \%$ ，胃全摘 54 例中 12 例， $22.2 \%$ に上昇 するが両術式間に差はみとめられなかった。

C群ではそれぞれ65例中 5 例， $7.7 \% ， 34$ 例中 5 例， 14.7\%と胃全摘に有意に多かった（表 3 ）.

胃再建術式別胆石発見率は食物が十二指腸を通るも の（以後通るものと略）と食物が十二指腸を通らない わの（以後通らないるのと略）とに分けて比較すると, $\mathrm{A}, \mathrm{B}$ 群では通るものの対象が少なく, 通らないものは A群146例中19例， $13.0 \%$ ，B群83例中 12 例, $14.5 \%$ で あった。 B 群の胆石発見症例をA群に加光ると146例中 31 例， $21.2 \%$ に上昇した。

C群では通るもの 55 例中 5 例, $9.1 \%$, 通らないもの 44例中 5 例， $11.4 \%$ と差はなかった（表 4 ）。

胆石発見時期は $\mathrm{A}$ 群では術後 $1 \sim 6$ 年にわたってお り，19例中 15 例が 5 年以内に分布していた。 B 群でも 13 例中 11 例が 5 年以内に集中していた. $A, B$ 両群を合

表 5 胆石発見時期

\begin{tabular}{r|r|r|r|r|r|r|r|c}
\hline $\begin{array}{c}\text { 術後 } \\
\text { 年数 }\end{array}$ & $\sim 1$ & $\sim 2$ & $\sim 3$ & $\sim 4$ & $\sim 5$ & $\sim 6$ & $\sim 7$ & $\sim 8$ \\
\hline $\mathrm{A}$ 群 & & 5 & 4 & 2 & 2 & 2 & 4 & \\
$\mathrm{~B}$ 群 & & & 5 & 2 & 2 & 2 & & 2 \\
$\mathrm{C}$ 群 & & 3 & 3 & 4 & & & & \\
\hline 計 & & 8 & 12 & 8 & 4 & 4 & 4 & 2 \\
\hline
\end{tabular}

図 1 胃切除後 2 年 8 力月目の USG. 胆鸾内飞 strong echo と acoustic shadowを伴う結石陰影を みとめる。

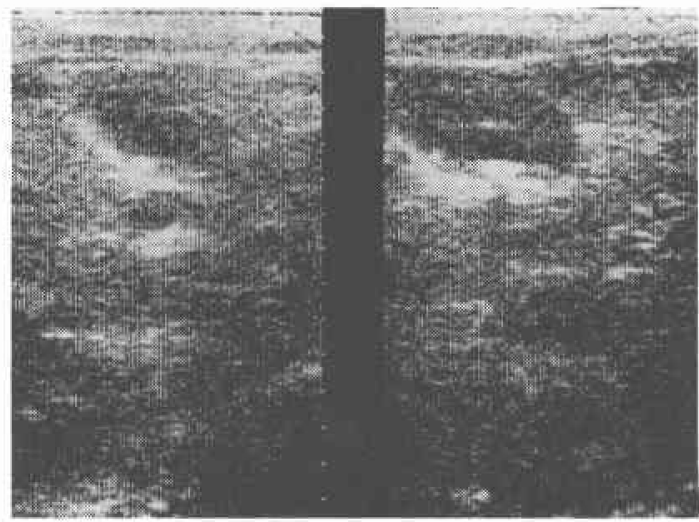

わせると 32 例中 26 例， $81.3 \%$ が 5 年以内に発見された ことになる。なお，B群の 7 年以内の 2 例はいずれも 昭和50年の症例で56年の USG で胆石なし，57年以降 のUSGで胆石ありと判定されている．C群では 1 年 および 2 年以内各 3 例, 3 年以内 4 例であった(表 5 ).

\section{III. 症例}

1. 60 歳, 男性, 胃切除(BIIa)後 2 年 8 力月目の USG で胆震内に移動性を有する strong echo と acoustic shadowをともなら明らかな結石陰影をみとめた（図 1)。なお，本例は術前より肝硬变症を合併していた。

2. 胃切除後 3 年 6 力月目, 激烈甲右季助部痛, 発熱

四 2 胃切除後 3 年 6 力月目の USG. 前回みとめら れた結石陰影はない。

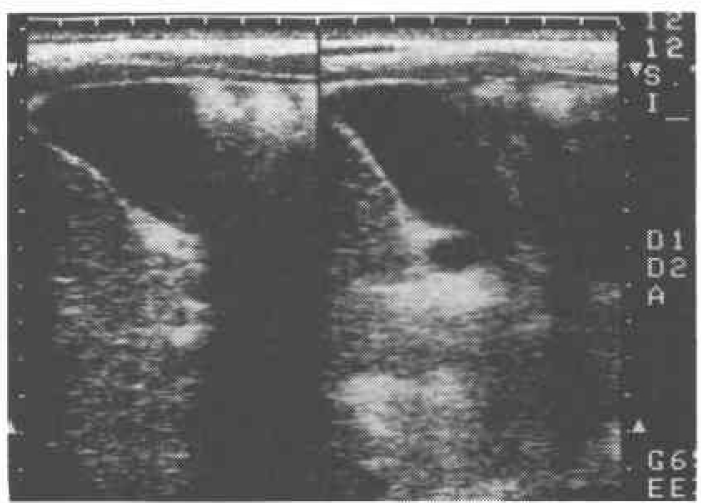

図 3 胃切除後 4 年 6 力月目の USG. 胆衰内に再び結 石陰影がみとめられる。

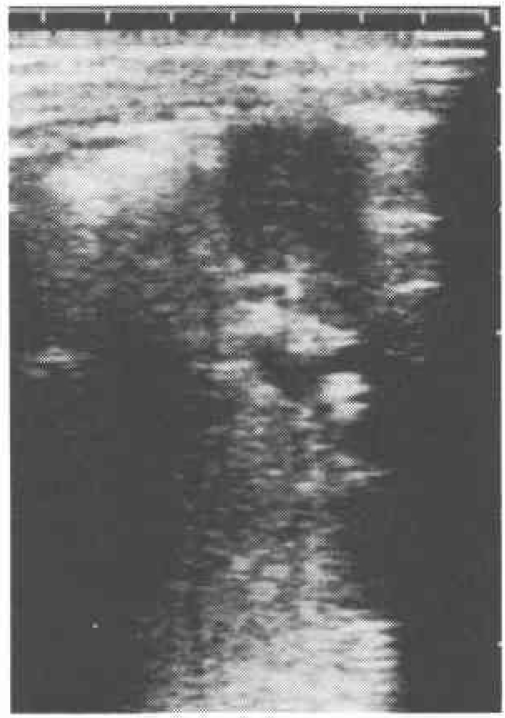


にて某院に入院，治療後の USG では前回みとめられ た結石陰影はいかなる走查方向からも証明できなかっ た（図 2).

3. 胃切除後 4 年 6 カ月目, 寸なわら疼痛発作後 1 年 目のUSG で結石の再発生がみとめられた（図 3）.

\section{IV. 総括と考察}

今, 仮りに胃切後胆石症の発生が高頻度にみられる ものとすれば, $\mathrm{R}_{2}$ 手術に際し胆霟摘除を併せ行うとい 万考忩が当然出てくる.この観点からも本症の発生頻 度を正確に知ることは極めて大切なことといえよう。

一般に本症の主たる原因とされている迷切後に発生 する胆石症の頻度については10４0\% ${ }^{3) \sim 10)}$ とさまざ まであり，幹迷切で高く選択的迷切で低いと考党られ

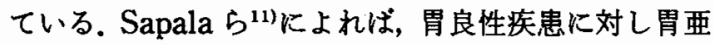
全摘のみでは胆石症の発生は $6 \%$ にすぎず，これに幹 迷切が加わると $21 \%$ に急増したとい5，自験例の迷切 の程度は既述したごとく全例完全な幹迷切に相当し， 発生頻度に関してはSapala ら ${ }^{11)}$ の報告が目安になろ 5 .

しかし，前述の報告3 〜11はいずれも結石の有無を胆 襄造影で判定したものであり，自験例のようにUSG にて follow up したものはほとんどないのが現状であ る. 結石の存在診断はもはやUSG の時代であり,これ なくして胃切後胆石症を論ずるのは難しい，事実

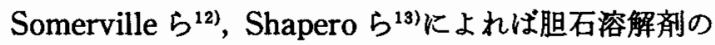
効果判定に用いられた胆亳造影で結石消失とされた症 例の中に, USG で結石をみとめたものがあったとい 5. 自験例でも術前, 術後の USG が全例に施行される ようになったのは昭和54年以降であり，この意味での データ（5年以上 follow up 例が 5 年間分集積）が出 そろらには昭和63年まで待たなりればならない。

しかし，B群は術後の USG が主体とはい方定期的 USG 4 ～10年経過例であり，自験例では本症の $80 \%$ 以上が術後 5 年以内に集中していること，A群の胆石 発見症例19例を除いていることなどを考虑すると，B 群の胆石発見率15.3\%は本症発生の下限と考えられ る.一方， B 群の胆石発見症例を $\mathrm{A}$ 群に組み入れた胆 石発見率 $21.8 \%$ はその上限と推測される. 結局胃切後 胆石症の発生頻度は $20 \%$ 前後と思われる。

男女別頻度については通常の胆石症が女性に多いの にくらべ, A, B 群合わせたものでは性別差がみられな かった，むしろB群，C群では男に多い傾向にあり， 本症発生に手術の影響の大きいことが示唆される成績 であった。
胃切除術式別頻度は A, B 両群共に胃亜全摘, 胃全 摘間に差はなく，迷切が本症発生の主な原因とすれば らなずける結果であった。しかし，C群では胃全摘で 異亜全摘より有意に高く，観察期間が短いため確たる ことはいえないがこれからの follow up が肝要と思わ れた。

最近, 長期間絶食のため中心静脈栄養にて管理した

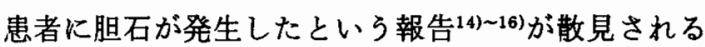
ようである．その原因としては食物が十二指腸を通過 しないため cholecystokininが分泌されず，その結果 胆囊が収縮せず胆汁がうっ滞するためと考克られてい る.この観点に立てば通るすの（B-I および空腸間置） と通らないもの（B-II および $\rho$ 吻合）との間には当然 差が出てくるはずである.しかし， A, B 群では通るも のの症例が少ないため両者を比較検討することができ なかった，C群では通るものと通らないものとの胆石 発見率はほぼ同様であったが, follow upの期間が短 かく，また症例も少ないことより今後の検索を待たな ければならない。なお，自験例に 2 週間以上の絶食例 はない。

胆囊結石の自然消失のメカニズム17) 199 については， 胆囊と腸管との間に瘻孔を形成したものを除けば, もっともポプニラーなものとして胆襄管より総胆管を 経て十二指腸への結石の排出が考えられ，腹痛をとも なら場合とともなわない場合とがある。 また，代謝性 溶解（低脂肪食によるウェートコントロールなどに際 して）なども考えられている。自験例は臨床症状より 考点, 結石は腹痛をともなって十二指腸へ排出し, 発 作後 1 年で結石の再発をみたものと思われる，本例は 肝硬変症といら特殊な状態に加え, 結石生成の準備状 態にある胆襄とも考えられた。

胆震結石の自然消失が時々見られるるのとすれば， 胃切後胆石症の検索には十分な注意が必要である。幸 い自験例でかかる経過をとった症例は現在までのとこ ろ本例のみであり，湾かに結石の縮小傾向を示したも のはみられなかった。

\section{V.むすひ}

胃切後胆石症の発生頻度について種々の点より言及 した，その結果は要約すると以下のごとくであった。

1）胃切後胆石症の頻度は $20 \%$ 前後と推測された。

2) 男女別, 胃切除術式別战よび胃再建術式別にみた 本症の発生頻度は, それぞれいずれの項目でも差はみ られなかった。 


\section{文 嗝}

1）杉山 譲, 小沢正則, 華表克次注か：胃癌切除後胆 石症について，日消外会誌 $16: 879-884,1983$

2) Sugiyama $Y$, Ozawa $M$, Sohma $H$ et al : Gallstone disease secondary to stomach cancer surgery. Hirosaki Med J 36 : 308-315, 1984

3) Clave RA, Gasper MR : Incidence of gallbladder disease after vagotomy. Am J Surg 118 : 169-176, 1969

4) Inberg MV, Vuorio $M$ : Human gallbladder function after selective gastric and total abdominal vagotomy. Acta Chir Scand 135: 625-633, 1969

5) Tompkins RK, Kraft AR, Zimmerman $E$ et al : Clinical and biochemical evidence of increased gallstone formation after complete vagotomy. Surgery $71: 196-200,1972$

6) Parkin GJ, Smith RB, Johnston D: Gallbladder volume and contractility after truncal, selective and highly selective (parietal-cell) vagotomy in man. Ann Surg $178: 581-586$, 1973

7) Ihasz M, Wachtl I, Kiss L et al: Incidence of cholelithiasis after truncal and selective vagotomy. Acta Chir Acad Sci Hung 18: 115-121, 1977

8) Csendes A, Larach J, Godoy M : Incidence of gallstones development after selective hepatic vagotomy. Acta Chir Scand $114: 289-291,1978$

9) Anderson JR, Ross AHM, Din NA et al: Cholelithiasis following peptic ulcer surgery : A prospective controlled study. Br J Surg 67: $618-620,1980$

10) Ihasz M, Griffith CA: Gallstones after vagotomy. Am J Surg 141:48-50, 1981

11) Sapala MA, Sapala JA, Soto ADR et al: Cholelithiasis following subtotal gastric resection with truncal vogotomy. Surg Gynecol Obstet $148: 36-38,1979$

12) Somerville KW, Rose DH, Bell GD et al : Gallstone dissolution and recurrence : Are we being misled? Br Med J 284: 1295-1298, 1982

13) Shapero TF, Rosen IE, Wilson $S R$ et al: Discrepancy between ultrasound and oral cholecystography in the assessment of gallstone dissolution. Hepatology $2: 587-590,1982$

14) Messing B, Bories $C$, Kunstringer $F$ et al: Does total parenteral nutrition induce gallbladder sludge formation and lithiasis? Gastroenterology $84: 1012-1019,1983$

15) Pitt HA, King W III, Mann LL et al: Increased risk of cholelithiasis with prolonged total parenteral nutrition. Am J Surg 145: 106-112, 1983

16) Roslyn JJ, Berquist WE, Pitt $\mathrm{HA}$ et al: Increased risk of gallstones in children receiving total parenteral nutrition. Pediatrics 71 : $784-789,1983$

17) Norman $\mathrm{CH}$ Jr, Butera DG: Spontaneously disappearing gallstones. J Natl Med Assoc 71 : 61, 1971

18) Liebermann TR: Spontaneous disappearance of gallstones. Gastrointest Radiol $4: 265-267$, 1979

19) Ahlberg J, Einarsson K, Westberg G: Spontaneous dissolution of gallstones. A case report. Acta Chir Scand Suppl 500 : 3-5, 1980 